\title{
Efficiency of Osmotic Dehydration of Pomegranate Seeds in Polyols Solutions Using Response Surface Methodology
}

\author{
Brahim Bchir ${ }^{1,2, * \mathbb{D}}$, Haifa Sebii ${ }^{1}$, Sabine Danthine ${ }^{3} \mathbb{D}$, Christophe Blecker $^{3}$, Souhail Besbes ${ }^{1}$, Hamadi Attia ${ }^{1}$ \\ and Mohamed Ali Bouaziz ${ }^{1}$ (D)
}

1 Laboratory of Analysis Valorization and Food Safety, National Engineering School of Sfax, University of Sfax, Sfax BP W-3038, Tunisia; haifasebii@gmail.com (H.S.); besbes_souhail@yahoo.fr (S.B.); hamadi.attia@gmail.com (H.A.); medalibouaziz@yahoo.fr (M.A.B.)

2 Higher Institute of Biotechnology of Monastir, University of Monastir, Avenue Taher Hadded BP 74, Monastir 5000, Tunisia

3 Laboratory of Food Science and Formulation, University of Liège, Gembloux Agro-Bio Tech, Passage des Déportés 2 B, B-5030 Gembloux, Belgium; sabine.danthine@uliege.be (S.D.); christophe.blecker@uliege.be (C.B.)

* Correspondence: brahim.bchir@isbm.u-monastir.tn; Tel.: +216-53-440-380

Citation: Bchir, B.; Sebii, H.; Danthine, S.; Blecker, C.; Besbes, S.; Attia, H.; Bouaziz, M.A. Efficiency of Osmotic Dehydration of Pomegranate Seeds in Polyols Solutions Using Response Surface Methodology. Horticulturae 2021, 7, 268. https:// doi.org/10.3390/horticulturae7090268

Academic Editor: Rosario Paolo Mauro

Received: 23 July 2021

Accepted: 25 August 2021

Published: 28 August 2021

Publisher's Note: MDPI stays neutral with regard to jurisdictional claims in published maps and institutional affiliations.

Copyright: (c) 2021 by the authors. Licensee MDPI, Basel, Switzerland. This article is an open access article distributed under the terms and conditions of the Creative Commons Attribution (CC BY) license (https:// creativecommons.org/licenses/by/ $4.0 /)$.
Abstract: This study investigates the influence of polyol compounds (sorbitol and erythritol) on the osmotic dehydration process of pomegranate seeds. The efficacy of the osmotic dehydration process was estimated based on the determination of water loss, weight reduction, solid gain, and effective diffusivity and also through a comparison of the results obtained between sucrose and polyol osmotic solutions. Response surface methodology was used to optimize the osmotic process. Quality attributes of pomegranate seeds were determined through the assessment of physical (texture and color) characteristics. This innovative research applies alternative solutions in the osmotic process, which until now, have not been commonly used in the osmotic dehydration of pomegranate seeds processing by researchers worldwide. Results revealed the excellent correlation of experimental values with the model. Erythritol and sorbitol exhibit stronger efficiency than sucrose. However, erythritol was not satisfactory due to the high solid gain. Therefore, the sorbitol osmotic agent seems to be the most suitable for the osmotic dehydration of pomegranate seeds. The optimal condition for maximum water loss $(38.61 \%)$, weight reduction $(37.77 \%)$, and effective diffusivity $\left(4.01 \times 10^{-8} \mathrm{~m}^{2} / \mathrm{s}\right)$ and minimum solid gain $(-0.37 \%)$ were $13.03 \mathrm{~min}, 27.77^{\circ}$ Brix, and $37.7^{\circ} \mathrm{C}$, using a sorbitol solution. Results of texture and color revealed the major impact of erythritol and sorbitol osmotic agents on seed characteristics during the osmotic dehydration process.

Keywords: osmotic dehydration; polyol; pomegranate seeds; solid gain; water loss; effective diffusivity; response surface methodology; texture; color

\section{Introduction}

The enormous consumption of sugars, principally sucrose, results in the increased incidence of various diseases (hyperactivity in children, type 2 diabetes, dyslipidemia and cardiovascular diseases), which is why safe substitutes are sought [1]. However, sucrose is the most common substance employed in the formulation of many foods to modulate their taste values and in the elaboration of osmotic solutions [2]. The most notable property of sugar in food is its sweet taste [3]. Therefore, a new world health organization guideline consigns children and adults to decrease their daily intake of free sugars to less than $10 \%$ of their total energy intake [4]. A further reduction to below 5\% or roughly $25 \mathrm{~g}$ per day would provide additional health benefits [4]. Research indicates that children with the highest intakes of sugar-sweetened drinks are more likely to be overweight or obese than children with a low intake of sugar-sweetened drinks [4].

Polyols could be used as an alternative to replacing sucrose by reason of its low calories and relative sweetness of around $60-100 \%$ compared with sucrose [4]. Polyols 
constitute a group of sweeteners, also known as hydroxyl alcohols, sugars, or polyalcohols. They occur naturally in vegetables, fruits, and mushrooms [5]. Polyols sweeteners have a lower sweetening power compared to sucrose. Polyols are slowly absorbed in the digestive system, which does not lead to a rapid increase in blood glucose level [2]. Therefore, these products are recommended for people with diabetes $[5,6]$.

Recently, polyol substances, such as steviol, maltitol, erythritol, and xylitol, have been used as an alternative to sucrose for the osmotic treatment of foodstuffs [7-9]. Indeed, several authors [10-16] have used sorbitol, erythritol, glycerol, maltitol, and xylitol, respectively, as an alternative to sucrose solutions for the osmotic dehydration (OD) of many fruits. OD is the process of partial water removal from the tissue by putting the fruit in a hypertonic osmotic solution [16]. Osmotic dehydration could prolong the shelflife of pomegranate seeds by preserving their nutritional components [17]. According to Bchir et al. [17], the international production of pomegranate seeds was over 1,000,000 $t$ in 2018. Pomegranate seeds are generally consumed during the harvest season. Hence, for extending the shelf-life of pomegranate seeds further processing, such as osmotic dehydration, is a necessity. However, until now, the use of polyols has not been common in the OD of pomegranate seeds by researchers worldwide.

The aim of the present study is (a) to evaluate the influence of two polyols, erythritol and sorbitol, on the OD kinetics of pomegranate seeds, searching for the optimal operating conditions (temperature, ${ }^{\circ}$ Brix, and immersion time) that minimize solid gain, and maximize water loss, weight reduction, and effective diffusivity, using response surface methodology and (b) to study the effect of polyol osmotic agents on the texture and color of the pomegranate seeds' surface compared to the control (sucrose).

\section{Materials and Methods}

\subsection{Materials}

Pomegranate fruits (Punica granatum L.) from the 'El-Gabsi' variety were acquired from the experimental field in Gabes (Tunisia) at full ripeness. The fruits were cleaned with wet paper, wiped carefully, and then stored at $4{ }^{\circ} \mathrm{C}$ until analysis. Before experimentations, seeds were collected in bottles and left at room temperature.

\subsection{Osmotic Dehydration Treatment}

Pomegranate seeds were dehydrated by OD in a shaking water bath with an oscillation rate of $160 \mathrm{rpm}$ (GFL Instrument D 3006, Schônwalde-Glien, Germany). Osmotic solutions were conducted with substances from the polyol group, purchased from Brenntag company (Kedzierzyn-Kozle, Poland) (erythritol and sorbitol) and distilled water to reach a concentration of 20 and $40{ }^{\circ}$ Brix. Sucrose was used as a control to compare the OD process kinetics. OD was carried out for $60 \mathrm{~min}$ at different temperatures $\left(30^{\circ} \mathrm{C}, 40^{\circ} \mathrm{C}\right.$, and $50{ }^{\circ} \mathrm{C}$ ) and using a 4:1 syrup-to-fruit ratio. Then, the samples were taken from the osmotic solution and blotted with absorbent paper to remove excess osmotic liquid from their surface. Then, samples were weighed and dry matter, as well as weight reduction $(\mathrm{WR})$, solid gain $(\mathrm{SG})$, water loss $(\mathrm{WL})$, and effective diffusivity $\left(\mathrm{D}_{\text {eff }}\right)$, were determined according to Bchir et al. [17].

\subsection{Experimental Design}

A Box-Behnken design with three variables at three levels was applied to determine the responses and then to characterize the optimal combination of variables for the OD process (Table 1). Temperature, ${ }^{\circ}$ Brix, and time were the independent variables. On the other hand, weight reduction, solid gain, effective diffusivity, and water loss correspond to the dependent variables. Fifteen experimental points were presented by the complete design (Table 2). 
Table 1. The level of coded values used for the osmotic dehydration process.

\begin{tabular}{ccccc}
\hline \multirow{2}{*}{ Coded Factor } & \multirow{2}{*}{ Independent Variables } & \multicolumn{3}{c}{ Coded Levels of Variables } \\
\cline { 3 - 5 } & Temperature $\left({ }^{\circ} \mathrm{C}\right)$ & $\mathbf{- 1}$ & $\mathbf{0}$ & $\mathbf{1}$ \\
\hline $\mathrm{X} 1$ & Time $(\min )$ & 10 & 40 & 50 \\
\hline $\mathrm{X} 2$ & ${ }^{\circ} \mathrm{Brix}(\%)$ & 0 & 20 & 60 \\
\hline $\mathrm{X} 3$ & & &
\end{tabular}

Table 2. Box-Ben design matrix with experimental values of response variables for the OD of pomegranate seeds in different osmotic solutions.

\begin{tabular}{|c|c|c|c|c|c|c|c|c|c|c|c|c|c|c|}
\hline \multirow[t]{2}{*}{$\overline{X 1}$} & \multirow[t]{2}{*}{$\mathrm{X} 2$} & \multirow[t]{2}{*}{$\mathrm{X3}$} & \multicolumn{4}{|c|}{ Erythritol } & \multicolumn{4}{|c|}{ Sorbitol } & \multicolumn{3}{|c|}{ Sucrose } & \multirow[b]{2}{*}{$D_{\text {eff }}$} \\
\hline & & & WL & SG & WR & $D_{\text {eff }}$ & WL & SG & WR & $D_{\text {eff }}$ & WL & SG & WR & \\
\hline 40 & 60 & 40 & 32.96 & 3.64 & 40.61 & $4.22 \times 10^{-8}$ & 32.24 & 9.08 & 41.10 & $4.10 \times 10^{-8}$ & 28.09 & -1.31 & 38.41 & $4.03 \times 10^{-8}$ \\
\hline 50 & 35 & 40 & 38.58 & -0.78 & 39.36 & $4.74 \times 10^{-8}$ & 33.40 & -1.35 & 32.05 & $3.70 \times 10^{-8}$ & 35.02 & 0.66 & 30.37 & $4.70 \times 10^{-8}$ \\
\hline 40 & 10 & 0 & 40.83 & -8.84 & 31.98 & $1.75 \times 10^{-8}$ & 34.56 & -7.70 & 26.85 & $1.75 \times 10^{-8}$ & 20.86 & -4.76 & 43.62 & $1.50 \times 10^{-8}$ \\
\hline 30 & 60 & 20 & 28.49 & -1.36 & 27.12 & $2.11 \times 10^{-8}$ & 32.04 & 1.00 & 33.04 & $1.80 \times 10^{-8}$ & 26.34 & -3.56 & 29.90 & $2.80 \times 10^{-8}$ \\
\hline 50 & 60 & 20 & 36.64 & -3.29 & 33.35 & $4.74 \times 10^{-8}$ & 34.59 & -5.28 & 29.30 & $4.71 \times 10^{-8}$ & 37.95 & -4.55 & 38.50 & $3.80 \times 10^{-8}$ \\
\hline 40 & 35 & 20 & 36.85 & -3.65 & 33.20 & $3.75 \times 10^{-8}$ & 37.92 & -0.33 & 37.58 & $3.20 \times 10^{-8}$ & 35.98 & -4.45 & 40.42 & $2.74 \times 10^{-8}$ \\
\hline 50 & 35 & 0 & 41.48 & -10.16 & 31.21 & $1.75 \times 10^{-8}$ & 36.67 & -8.93 & 27.73 & $1.75 \times 10^{-8}$ & 25.93 & -5.20 & 38.81 & $2.80 \times 10^{-8}$ \\
\hline 30 & 35 & 0 & 36.91 & -9.91 & 26.99 & $1.75 \times 10^{-8}$ & 34.76 & -9.03 & 25.72 & $1.75 \times 10^{-8}$ & 20.13 & -5.15 & 35.29 & $1.20 \times 10^{-8}$ \\
\hline 40 & 60 & 0 & 37.88 & -10.63 & 27.25 & $1.75 \times 10^{-8}$ & 25.80 & -9.15 & 26.64 & $1.75 \times 10^{-8}$ & 28.09 & -5.31 & 38.41 & $1.80 \times 10^{-8}$ \\
\hline 40 & 35 & 20 & 36.85 & -3.65 & 33.20 & $3.75 \times 10^{-8}$ & 37.92 & -0.33 & 37.56 & $3.20 \times 10^{-8}$ & 35.98 & -4.45 & 40.42 & $2.74 \times 10^{-8}$ \\
\hline 50 & 10 & 20 & 34.48 & 7.24 & 41.73 & $4.74 \times 10^{-8}$ & 36.38 & -0.25 & 36.13 & $4.71 \times 10^{-8}$ & 37.56 & -3.97 & 30.59 & $3.70 \times 10^{-8}$ \\
\hline 40 & 35 & 20 & 36.85 & -3.65 & 33.20 & $3.75 \times 10^{-8}$ & 37.92 & -0.33 & 37.56 & $3.20 \times 10^{-8}$ & 35.98 & -4.45 & 40.42 & $2.74 \times 10^{-8}$ \\
\hline 30 & 35 & 40 & 37.68 & 1.53 & 39.21 & $1.74 \times 10^{-8}$ & 31.80 & -5.90 & 37.71 & $1.90 \times 10^{-8}$ & 43.09 & -0.71 & 33.81 & $2.74 \times 10^{-8}$ \\
\hline 30 & 10 & 20 & 40.30 & -3.64 & 36.65 & $1.74 \times 10^{-8}$ & 38.61 & -2.29 & 36.31 & $1.73 \times 10^{-8}$ & 27.33 & -4.04 & 31.38 & $1.75 \times 10^{-8}$ \\
\hline 40 & 10 & 40 & 36.91 & 0.11 & 37.03 & $4.73 \times 10^{-8}$ & 37.60 & 9.42 & 47.41 & $4.80 \times 10^{-8}$ & 36.25 & -2.95 & 36.21 & $4.50 \times 10^{-8}$ \\
\hline
\end{tabular}

WL, SG, WR: \%-D $\mathbf{D}_{\text {eff }}: \mathrm{m}^{2} \mathrm{~s}^{-1}$.

\subsection{Optimization}

Response surface methodology was applied to the experimental data using the software Minitab. To depict the relationships between the independent variables (X1, X2, and $\mathrm{X} 3$ ) and the response (Y), a linear regression method of the polynomial model with 10 coefficients were used (Equation (1)).

$$
Y=\beta_{0}+\beta_{1} X_{1}+\beta_{2} X_{2}+\beta_{3} X_{3}+\beta_{12} X_{1} X_{2}+\beta_{13} X_{1} X_{3}+\beta_{23} X_{2} X_{3}+\beta_{11} X_{1}^{2}+\beta_{22} X_{2}^{2}+\beta_{33} X_{3}^{2}
$$

where $Y$ is the response variable of removal efficiency (WL, SG, WR, and $D_{\text {eff }}$ ); $\beta_{0}$ is the estimated coefficient of fitted response regression at the center point; $\beta_{1}, \beta_{2}$, and $\beta_{3}$ are linear coefficients; $\beta_{12}, \beta_{13}$, and $\beta_{23}$ are cross-product coefficients; $\beta_{11}, \beta_{22}$, and $\beta_{33}$ are quadratic coefficients.

\subsection{Statistical Analysis}

A nonparametric Kruskal-Wallis test at a 95\% level of confidence was used to determine the significant difference between parameters (WL, SG, WR, and $\mathrm{D}_{\text {eff }}$ ). The KruskalWallis nonparametric hypothesis test is a nonparametric analog of the one-way analysis of variance (ANOVA). It is used when the measurement variable does not meet the normality assumptions of one-way ANOVA. It is also a popular nonparametric test to compare outcomes among three or more independent groups. 


\subsection{Physical Analysis}

\subsubsection{Dry Matter}

Dry matter or total solids content of pomegranate seeds was calculated according to the method of Bchir et al. [17]. Approximately, $5 \mathrm{~g}$ of seeds were oven dried at $103^{\circ} \mathrm{C} \pm 2{ }^{\circ} \mathrm{C}$, until constant weight.

\subsubsection{Surface Color Measurement}

Color analysis of pomegranate seeds surface was measured with the use of a colorimeter (Hunterlab, Reston, VA, USA). The samples were put inside a glass refract cup on the light pore size of $44.40 \mathrm{~mm}$. The results were presented using the directly measured parameters: $L^{*}$ (lightness/darkness) ranges from 0 (black) to 100 (white), $b^{*}$ (yellow/blue) ranges from -100 (blue) to +100 (yellow), and $a^{*}$ (red/green) ranges from -100 (green) to +100 (red). The measurements were made in triplicate.

The total color difference $(\Delta \mathrm{E})$ was calculated according to the following Equation (2) [18].

$$
\Delta \mathrm{E}=\sqrt{\left(L^{*}-L_{0}^{*}\right)^{2}+\left(a^{*}-a_{0} *\right)^{2}+\left(b^{*}-b_{0}^{*}\right)^{2}}
$$

where $L^{*}, a^{*}$, and $b^{*}$ and $L_{0}^{*}, a_{0}^{*}$, and $b_{0}{ }^{*}$ are respectively the current and the initial color coordinates of pomegranate seeds' surface.

\subsubsection{Texture Analysis}

Texture profile analysis (hardness and toughness) was realized using a texturometer equipped with a $75 \mathrm{~mm}$ compression probe (TA-XT2 Texture Analyzer, Stable Micro Systems, Godalming, UK). The toughness ( $\mathrm{N} \mathrm{mm}$ ) is the energy required to crush the sample completely, while the hardness $(\mathrm{N})$ of the seed was taken as the force in compression that corresponded to the breakage of samples. The operating conditions of the instrument were as follows: $10.0 \mathrm{~mm} / \mathrm{s}$ post-test speed, $0.5 \mathrm{~mm} / \mathrm{s}$-test speed, $1.5 \mathrm{~mm} / \mathrm{s}$ pre-test speed, $0.10 \mathrm{~N}$ trigger force, and $85 \%$ sample deformation [19]. The measurements were made in triplicate.

\subsection{Weight Reduction Water Loss, Solid Gain, and Effective Diffusivity}

The water loss (WL), weight reduction (WR), and solid gain (SG) were measured according to the method proposed by Bchir et al. [17] (Equations (3)-(5)).

$$
\begin{gathered}
\mathrm{WR}(\%)=\frac{\left(W_{i}-W_{f}\right)}{W_{i}} \times 100 \\
\mathrm{SG}(\%)=\frac{\left(W_{s f}-W_{s i}\right)}{W_{i}} \times 100 \\
\mathrm{WL}(\%)=\mathrm{SG}+\mathrm{WR}
\end{gathered}
$$

where $W_{f}$ is the final weight of the sample $(\mathrm{g}) ; W_{i}$ is the initial weight of the sample $(\mathrm{g}) ; W_{s f}$ is the final total solids content $(\mathrm{g})$, and $W_{s i}$ is the initial total solids content $(\mathrm{g})$.

Diffusion coefficients $\left(D_{\text {eff }}\right)$ were measured using Fick's second law equation applied to a sphere [20]. The solution for Fick's equation law is given by Equation (6).

$$
W=\frac{\overline{M C(t)}-M C_{e q}}{M C_{0}-M C_{e q}}=\sum_{n=1}^{\infty} B_{n} \exp \left[-\mu_{n}^{2} F_{0}\right]
$$

where $B_{n}=6 / \mu_{n}{ }^{2} ; \mu_{n}=n \Pi ; F_{0}=\mathrm{D}_{\text {eff, }} \mathrm{t} / \mathrm{R}^{2} ; n=1,2,3, \ldots$ where $\mathrm{D}_{\text {eff }}$, is the effective diffusivity of water loss $\left(\mathrm{m}^{2} \mathrm{~s}^{-1}\right) ; n$ is the number of series terms; $\mathrm{R}$ is the equivalent radius of the sphere (m); $r$ is the distance in the radius direction $(\mathrm{m})$, and $t$ is the time $(\mathrm{s}) . W$ is the dimensionless amount of water loss; $\overline{M C(t)}$ is the amount of water at the instant $\mathrm{t}$ (g/g dry 
matter (DM)); $M C_{0}$ is the initial amount of water ( $\left.\mathrm{g} / \mathrm{g} \mathrm{DM}\right)$, and $M C_{e q}$ is the equilibrium amount of water loss (g/g DM) calculated using Equation (7).

$$
M C_{e q}=\lim _{t \rightarrow \infty}\left(M C_{0} \pm \frac{t}{k_{1}+k_{2} t}\right)=M C_{0} \pm \frac{1}{k_{2}}
$$

$k_{1}$ and $k_{2}$ are Peleg's parameters, and $t$ is the time (s) [21].

Peleg's equation parameter was obtained using Equation (8) [22].

$$
\overline{M C(t)}=M C_{0} \pm \frac{t}{k_{1}+k_{2} t}
$$

The diffusion coefficient calculated from Equation (6) has been corrected by the factor $\Psi^{2}$ due to the ellipsoid shape of pomegranate seeds as reported by Bchir et al. [20].

\section{Results and Discussion}

\subsection{Statistical Analysis}

The results revealed a significant difference $(p<0.05)$ only for WL $(p=0.029)$. However, SG $(p=0.358)$, WR $(p=0.135)$, and $D_{\text {eff }}(p=0.931)$ for all osmotic solutions did not present a significant difference $(p>0.05)$.

The position of all variables and their interactions in independent variables were determined using the quadratic model. Analysis of variance and the lack of fit were checked to evaluate, respectively, the sufficiency of the model and the variation of the data around the fitted model designed.

The lack of fit of WL, SG, WR, and $D_{\text {eff }}$ for the OD of pomegranate seeds in all osmotic solutions is not significant $(p>0.05)$ relative to the pure error, showing a good response to the model. Lack of fit is the variation of the data around the fitted model [20].

Results of regression and ANOVA analysis showed that the models were significant $(0.001<p<0.050)$ for all dependent variables (Tables 3-5).

Furthermore, ANOVA for WR, SG, WL, and $\mathrm{D}_{\text {eff }}$ showed that the second-order polynomial model was adequate to represent the actual relationship between the response and the variables with a high value of the coefficient of determination $\left(R^{2}\right)$. In fact, ANOVA analysis for $W R, S G, W L$, and $D_{\text {eff }}$ revealed a high value of $R^{2}$ (erythritol: $W L: R^{2}=0.95$; SG: $R^{2}=0.93$; WR: $R^{2}=0.89 ; D_{\text {eff }}: R^{2}=0.90$ /sorbitol: WL: $R^{2}=0.90 ; S G: R^{2}=0.96$; WR: $R^{2}=0.92 ; D_{\text {eff }}: R^{2}=0.83$ /sucrose: WL: $R^{2}=0.98$; SG: $R^{2}=0.92 ; W R: R^{2}=0.91$; $D_{\text {eff }}: R^{2}=0.95$ ). These results demonstrate that the model did not explain only a very low percentage of the sample variation for $\mathrm{WR}, \mathrm{SG}, \mathrm{WL}$, and $\mathrm{D}_{\text {eff }}$.

In addition, high adequacy of the model was observed. Indeed, the values of the adjusted determination coefficients were very close to 1 (erytriol: $W L$ : adjusted $R^{2}=0.85$; SG: adjusted $R^{2}=0.82 ;$ WR: adjusted $R^{2}=0.71 ; D_{\text {eff }}$ : adjusted $R^{2}=0.81$ / sorbitol: WL: adjusted $R^{2}=0.72$; SG: adjusted $R^{2}=0.89 ;$ WR: adjusted $R^{2}=0.76$; $D_{\text {eff }}$ : adjusted $R^{2}=0.70 /$ sucrose: WL: adjusted $R^{2}=0.95$; SG: adjusted $R^{2}=0.79$; WR: adjusted $R^{2}=0.77 ; D_{\text {eff }}$ : adjusted $R^{2}=0.86$ ). Therefore, $R^{2}$ values and adjusted $R^{2}$ revealed that the models were suitable for the design space. 
Table 3. Analysis of variance and regression analysis for OD in the erythritol osmotic solution: weight reduction, solid gain, water loss, and effective diffusivity.

\begin{tabular}{|c|c|c|c|c|c|c|c|c|c|c|c|c|c|}
\hline \multirow[b]{2}{*}{ Source } & \multirow[b]{2}{*}{$d f$} & \multicolumn{3}{|c|}{ Water Loss } & \multicolumn{3}{|c|}{ Solid Gain } & \multicolumn{3}{|c|}{ Weight Reduction } & \multicolumn{3}{|c|}{ Effective Diffusivity } \\
\hline & & Coefficient & $\begin{array}{l}\text { Sum of } \\
\text { Squares }\end{array}$ & $p$-Value & Coefficient & $\begin{array}{l}\text { Sum of } \\
\text { Squares }\end{array}$ & $p$-Value & Coefficient & $\begin{array}{l}\text { Sum of } \\
\text { Squares }\end{array}$ & $p$-Value & Coefficient & $\begin{array}{l}\text { Sum of } \\
\text { Squares }\end{array}$ & $p$-Value \\
\hline Model & 9 & 43.70 & 136.60 & $0.011 *$ & 4.2 & 364.74 & $0.017^{*}$ & 46.4 & 263.79 & $0.050 *$ & $6.35 \times 10^{-8}$ & 23.75 & $0.020 *$ \\
\hline B. Time & 1 & -0.15 & 7.62 & 0.078 & -0.59 & 7.92 & 0.264 & -0.74 & 30.68 & 0.076 & $0.475 \times 10^{-8}$ & 9.30 & $0.014^{*}$ \\
\hline C. ${ }^{\circ}$ Brix & 1 & 0.44 & 34.18 & $0.005 *$ & 0.22 & 5.33 & 0.349 & 0.23 & 66.52 & $0.022 *$ & $0.0051 \times 10^{-8}$ & 0.00 & 0.996 \\
\hline $\mathrm{A}^{2}$ & 1 & $4.97 \times 10^{-3}$ & 14.57 & $0.028 *$ & $5.56 \times 10^{-3}$ & 18.23 & 0.114 & $-0.62 \times 10^{-3}$ & 0.23 & 0.854 & $-0.19 \times 10^{-10}$ & 1.90 & 0.069 \\
\hline$C^{2}$ & 1 & $2.71 \times 10^{-3}$ & 10.58 & $0.048 *$ & $3.12 \times 10^{-3}$ & 14.02 & 0.155 & $0.43 \times 10^{-3}$ & 0.26 & 0.844 & $0.019 \times 10^{-10}$ & 0.05 & 0.719 \\
\hline$A * B$ & 1 & $4.58 \times 10^{-3}$ & 3.35 & 0.203 & $0.63 \times 10^{-3}$ & 0.06 & 0.915 & $-5.09 \times 10^{-3}$ & 4.14 & 0.450 & $0.37 \times 10^{-10}$ & 2.25 & 0.054 \\
\hline$A * C$ & 1 & $0.50 \times 10^{-3}$ & 0.25 & 0.706 & $2.66 \times 10^{-3}$ & 7.06 & 0.288 & $2.16 \times 10^{-3}$ & 4.65 & 0.425 & $-0.02 \times 10^{-10}$ & 0.03 & 0.776 \\
\hline$B * C$ & 1 & $13.97 \times 10^{-3}$ & 48.77 & $0.003 *$ & $12.82 \times 10^{-3}$ & 41.08 & $0.035 *$ & $1.15^{*} \times 10^{-3}$ & 0.33 & 0.826 & $-0.04 \times 10^{-10}$ & 0.03 & 0.770 \\
\hline Residual & 5 & - & 7.81 & - & - & 25.03 & - & - & 30.81 & - & - & 1.78 & - \\
\hline Lack of fit & 3 & - & 7.81 & 0.098 & - & 25.03 & 0.124 & - & 30.81 & 0.110 & - & 1.78 & 0.202 \\
\hline Pure error & 2 & - & 0.00 & - & - & 0.00 & - & - & 0.00 & - & - & 0.00 & - \\
\hline $\begin{array}{c}\text { Adj } \\
\text { R-squared }\end{array}$ & - & 0.85 & - & - & 0.82 & - & - & 0.71 & - & - & 0.81 & - & - \\
\hline
\end{tabular}

* Significant terms at the $5 \%$ level. 
Table 4. Analysis of variance and regression analysis for osmotic dehydration in the sorbitol osmotic solution: weight reduction, solid gain, water loss, and effective diffusivity.

\begin{tabular}{|c|c|c|c|c|c|c|c|c|c|c|c|c|c|}
\hline \multirow[b]{2}{*}{ Source } & \multirow[b]{2}{*}{$d f$} & \multicolumn{3}{|c|}{ Water Loss } & \multicolumn{3}{|c|}{ Solid Gain } & \multicolumn{3}{|c|}{ Weight Reduction } & \multicolumn{3}{|c|}{ Effective Diffusivity } \\
\hline & & Coefficient & $\begin{array}{l}\text { Sum of } \\
\text { Squares }\end{array}$ & $p$-Value & Coefficient & $\begin{array}{l}\text { Sum of } \\
\text { Squares }\end{array}$ & $p$-Value & Coefficient & $\begin{array}{l}\text { Sum of } \\
\text { Squares }\end{array}$ & $p$-Value & Coefficient & $\begin{array}{l}\text { Sum of } \\
\text { Squares }\end{array}$ & $p$-Value \\
\hline Model & 9 & 39.60 & 69.20 & $0.044 *$ & 3.10 & 499.74 & $0.006 *$ & 44.70 & 478.98 & $0.032 *$ & $5.80 \times 10^{-8}$ & 19.17 & 0.014 * \\
\hline B. Time & 1 & 1.25 & 1.83 & 0.321 & 2.39 & 16.23 & 0.111 & 3.63 & 7.15 & 0.414 & $0.43 \times 10^{-8}$ & 7.39 & $0.039 *$ \\
\hline C. ${ }^{\circ}$ Brix & 1 & 0.09 & 19.49 & $0.016^{*}$ & 0.17 & 1.55 & 0.575 & 0.07 & 32.06 & 0.118 & $-0.53 \times 10^{-9}$ & 0.00 & 0.650 \\
\hline $\mathrm{A}^{2}$ & 1 & $5.15 \times 10^{-3}$ & 15.63 & 0.024 * & $-1.12 \times 10^{-3}$ & 0.74 & 0.695 & $-6.25 \times 10^{-3}$ & 23.09 & 0.171 & $-0.11 \times 10^{-10}$ & 0.75 & 0.377 \\
\hline $\mathrm{B}^{2}$ & 1 & $17.00 \times 10^{-3}$ & 10.67 & $0.045 *$ & $-25.7 \times 10^{-3}$ & 24.38 & 0.064 & $42.6 \times 10^{-3}$ & 67.10 & $0.041 *$ & $-0.47 \times 10^{-10}$ & 0.82 & 0.358 \\
\hline$C^{2}$ & 1 & $1.30 \times 10^{-3}$ & 2.43 & 0.261 & $1.91 \times 10^{-3}$ & 5.29 & 0.319 & $0.63 \times 10^{-3}$ & 0.56 & 0.812 & $0.81 \times 10^{-11}$ & 0.96 & 0.324 \\
\hline$A * B$ & 1 & $0.39 \times 10^{-3}$ & 0.02 & 0.904 & $-9.19 \times 10^{-3}$ & 13.50 & 0.138 & $-9.58 \times 10^{-3}$ & 14.67 & 0.258 & $0.22 \times 10^{-10}$ & 0.81 & 0.362 \\
\hline$A * C$ & 1 & $3.30 \times 10^{-3}$ & 10.89 & $0.044 *$ & $0.56 \times 10^{-3}$ & 0.31 & 0.800 & $-2.74 \times 10^{-3}$ & 7.52 & 0.403 & $-0.03 \times 10^{-11}$ & 0.01 & 0.970 \\
\hline$B * C$ & 1 & $4.78 \times 10^{-3}$ & 5.72 & 0.110 & $-8.33 \times 10^{-3}$ & 17.36 & 0.102 & $-3.55 \times 10^{-3}$ & 3.14 & 0.580 & $-0.01 \times 10^{-10}$ & 0.01 & 0.970 \\
\hline Residual & 5 & - & 7.58 & - & - & 21.65 & - & - & 45.11 & - & - & 4.02 & - \\
\hline Lack of fit & 3 & - & 7.58 & 0.084 & - & 21.65 & 0.230 & - & 45.11 & 0.078 & - & 4.02 & 0.301 \\
\hline Pure error & 2 & - & 0.00 & - & - & 0.00 & - & - & 0.00 & - & - & 0.00 & - \\
\hline $\begin{array}{c}\text { Adj } \\
\text { R-squared }\end{array}$ & - & 0.72 & - & - & 0.89 & - & - & 0.76 & - & - & 0.70 & - & - \\
\hline
\end{tabular}

* Significant terms at the $5 \%$ level. 
Table 5. Analysis of variance and regression analysis for OD in the sucrose osmotic solution: weight reduction, solid gain, water loss, and effective diffusivity.

\begin{tabular}{|c|c|c|c|c|c|c|c|c|c|c|c|c|c|}
\hline \multirow[b]{2}{*}{ Source } & \multirow[b]{2}{*}{$d f$} & \multicolumn{3}{|c|}{ Water Loss } & \multicolumn{3}{|c|}{ Solid Gain } & \multicolumn{3}{|c|}{ Weight Reduction } & \multicolumn{3}{|c|}{ Effective Diffusivity } \\
\hline & & Coefficient & $\begin{array}{l}\text { Sum of } \\
\text { Squares }\end{array}$ & $p$-Value & Coefficient & $\begin{array}{l}\text { Sum of } \\
\text { Squares }\end{array}$ & $p$-Value & Coefficient & $\begin{array}{l}\text { Sum of } \\
\text { Squares }\end{array}$ & $p$-Value & Coefficient & $\begin{array}{l}\text { Sum of } \\
\text { Squares }\end{array}$ & $p$-Value \\
\hline Model & 9 & 32.30 & 1267.60 & $0.001 *$ & 0.65 & 41.41 & $0.023 *$ & 40.50 & 219.23 & $0.029 *$ & $4.23 \times 10^{-8}$ & 17.35 & 0.008 * \\
\hline B. Time & 1 & 2.24 & 149.39 & $0.002 *$ & -0.55 & 0.021 & 0.866 & 4.78 & 14.83 & 0.108 & $0.10 \times 10^{-8}$ & 5.36 & $0.002 *$ \\
\hline C. ${ }^{\circ}$ Brix & 1 & 0.19 & 8.95 & 0.217 & 0.057 & 0.124 & 0.683 & -0.23 & 0.25 & 0.811 & $0.017 \times 10^{-8}$ & 0.35 & 0.210 \\
\hline $\mathrm{A}^{2}$ & 1 & $2.93 \times 10^{-3}$ & 5.07 & 0.337 & $2.86 \times 10^{-3}$ & 4.848 & 0.043 * & $2.46 \times 10^{-3}$ & 3.57 & 0.382 & $0.31 \times 10^{-11}$ & 0.05 & 0.586 \\
\hline $\mathrm{B}^{2}$ & 1 & $-23.6 \times 10^{-3}$ & 20.50 & 0.086 & $6.99 \times 10^{-3}$ & 1.804 & 0.160 & $60.9 \times 10^{-3}$ & 136.91 & $0.002 *$ & $0.05 \times 10^{-10}$ & 0.01 & 0.982 \\
\hline $\mathrm{C}^{2}$ & 1 & $2.12 \times 10^{-3}$ & 6.49 & 0.283 & $-0.45 \times 10^{-3}$ & 0.29 & 0.535 & $-2.79 \times 10^{-3}$ & 11.24 & 0.150 & $0.43 \times 10^{-11}$ & 0.26 & 0.268 \\
\hline$A * B$ & 1 & $1.41 \times 10^{-3}$ & 0.32 & 0.800 & $1.78 \times 10^{-3}$ & 0.50 & 0.422 & $-4.95 \times 10^{-3}$ & 3.92 & 0.361 & $0.50 \times 10^{-11}$ & 0.04 & 0.648 \\
\hline$A * C$ & 1 & $2.70 \times 10^{-3}$ & 7.26 & 0.259 & $1.09 \times 10^{-3}$ & 1.20 & 0.236 & $2.71 \times 10^{-3}$ & 7.33 & 0.228 & $-0.35 * 10^{12}$ & 0.01 & 0.936 \\
\hline$B * C$ & 1 & $1.39 \times 10^{-3}$ & 0.48 & 0.756 & $-1.06 \times 10^{-3}$ & 0.28 & 0.545 & $9.39 \times 10^{-3}$ & 22.02 & 0.063 & $-0.95 \times 10^{-11}$ & 0.22 & 0.302 \\
\hline Residual & 5 & - & 22.43 & - & - & 3.31 & - & - & 19.45 & - & - & 0.85 & - \\
\hline Lack of fit & 3 & - & 22.43 & 0.101 & - & 3.31 & 0.527 & - & 19.45 & 0.317 & - & 0.85 & 0.152 \\
\hline Pure error & 2 & - & 0.00 & - & - & 0.00 & - & - & 0.00 & - & - & 0.00 & - \\
\hline $\begin{array}{c}\text { Adj } \\
\text { R-squared }\end{array}$ & - & 0.95 & - & - & 0.79 & - & - & 0.77 & - & - & 0.86 & - & - \\
\hline
\end{tabular}

* Significant terms at the $5 \%$ level. 


\subsection{Effect of Osmotic Agents on WL, SG, WR, and $D_{\text {eff }}$}

\subsubsection{Water Loss}

WL is a major parameter of mass transfer that shows the efficiency of the osmotic dehydration process. Tables $3-5$ show the analysis of variance and regression analysis for weight reduction, water loss, solid gain, and effective diffusivity during the OD of pomegranate seeds in erythritol, sorbitol, and sucrose osmotic solution. A sucrose osmotic agent was used as a reference.

The linear term of ${ }^{\circ}$ Brix had the most significant $(p<0.05)$ effect on water loss when using erythritol and sorbitol osmotic solutions. Comparable results were found by Khan et al. [23] showing the enhancement of the solution concentration resulting in an increase of the osmotic pressure gradients and, hence, higher WL in solutions that contained xylitol, sorbitol, and erythritol agents. On the other hand, the linear term of time and temperature have the most significant $(p<0.05)$ effect on WL when using sucrose as an osmotic agent. The impact of temperature $\left(45^{\circ} \mathrm{C}\right.$ and $\left.60{ }^{\circ} \mathrm{C}\right)$ on the OD process was confirmed by Devic et al., [24]. In addition, Ferreari and Hubinger [25] revealed that temperature and time have a significant impact on water transfer during the OD of apricots and melon in sucrose osmotic solution. The quadratic terms for ${ }^{\circ}$ Brix and temperature and the interaction between ${ }^{\circ}$ Brix and time have a significant $(p<0.05)$ effect on the WL of pomegranate seeds subjected to OD in erythritol osmotic solution. The use of sorbitol as an osmotic agent revealed another terms that has a significant $(p<0.05)$ impact on the $\mathrm{WL}$, such as the interaction between temperature- ${ }^{\circ}$ Brix and the quadratic term of time and temperature.

The coefficient values (Tables $3-5$ ) show the maximum positive contribution of ${ }^{\circ}$ Brix ( $\beta=0.442)$ followed by temperature $(\beta=0.067)$ when using the erythritol agent. These results show an enhancement in WL with an increase in sugar concentration and temperature. This could be due to the large osmotic driving force between the dilute sap of seeds and the surrounding hypertonic medium. Cichowska et al. [11] showed that the increase of temperature leads to irreversible damage and a loss of selectivity of the cell membrane involving a higher osmotic pressure at the product/solution interface. Moreover, higher temperature raised diffusion coefficients, inducing higher mass transfer rates [17].

Pomegranate seeds subjected to treatment with sucrose show the maximum positive contribution of time $(\beta=2.240)$ followed by temperature $(\beta=0.498)$. Other researchers revealed similar results during the OD of different types of products $[8-10,12,17]$ using a sucrose solution.

Since the interaction of time $-{ }^{\circ}$ Brix and temperature $-{ }^{\circ}$ Brix, for both erythritol and sorbitol osmotic solution, had a significant effect $(p<0.05)$ on $W L$, the contour plot as showed in Figure 1 was considered. Results showed that the enhancement of ${ }^{\circ}$ Brix and temperature increased WL when using the sorbitol solution (time was held constant: $60 \mathrm{~min}$ ). On the other hand, the increase of ${ }^{\circ}$ Brix during a short time improved WL when using erythritol osmotic agent (temperature was held constant: $50^{\circ} \mathrm{C}$ ). Moreira et al. [26], Khan et al. [23], and Cichowska et al. [11] showed that the optimal time for the osmotic dehydration of apple slices using erythritol solution correspond to the beginning of the process ( $3 \mathrm{~h})$.

The coefficients estimated for WL were more accentuated in samples treated with solutions that contained erythritol (43.7), followed by sorbitol (39.6) and sucrose (32.3). Similar results were showed in research by Mendonça et al. [4] during the OD of strawberry slices using sucrose and sorbitol osmotic solutions $\left(60^{\circ} \mathrm{Brix} ; 6 \mathrm{~h} ; 30^{\circ} \mathrm{C}\right)$. They found that higher values of WL were found when the erythritol osmotic agent was used. In addition, Cichowska et al. [11] revealed that mass transfer during the osmotic dehydration in a $40 \%$ solution concentration of xylitol and erythritol was more effective compared to a sucrose solution. In addition, Kowalska et al. [1] showed that the highest WL was observed in apples osmotically dehydrated using erythritol solution during $1440 \mathrm{~min}$. This fact could be due to the different molecular weights of osmotic agents. In fact, erythritol has a lower molecular weight $(122.10 \mathrm{~g} / \mathrm{mol})$, followed by sorbitol $(182.17 \mathrm{~g} / \mathrm{mol})$ and 
sucrose $(342.3 \mathrm{~g} / \mathrm{mol})$. Therefore, an osmotic agent with a small molecular weight favors the highest WL.

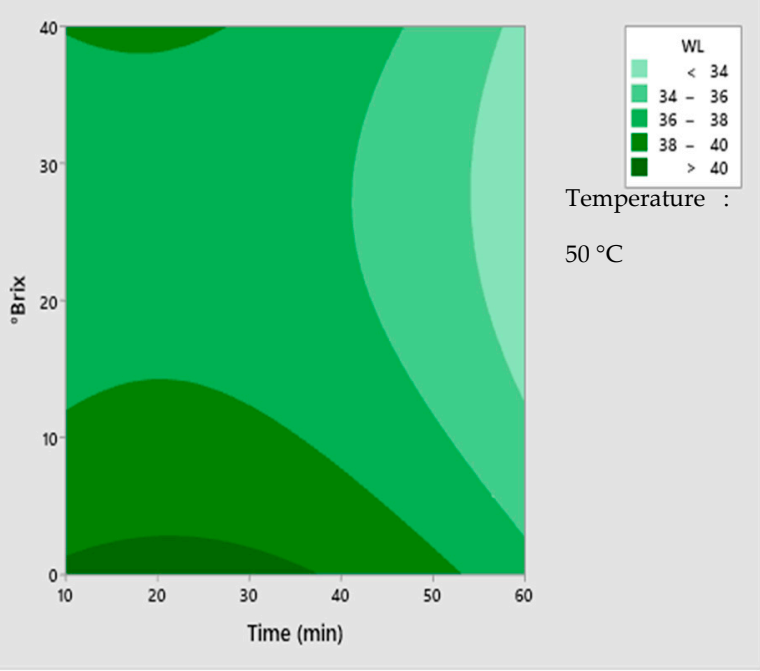

(a)

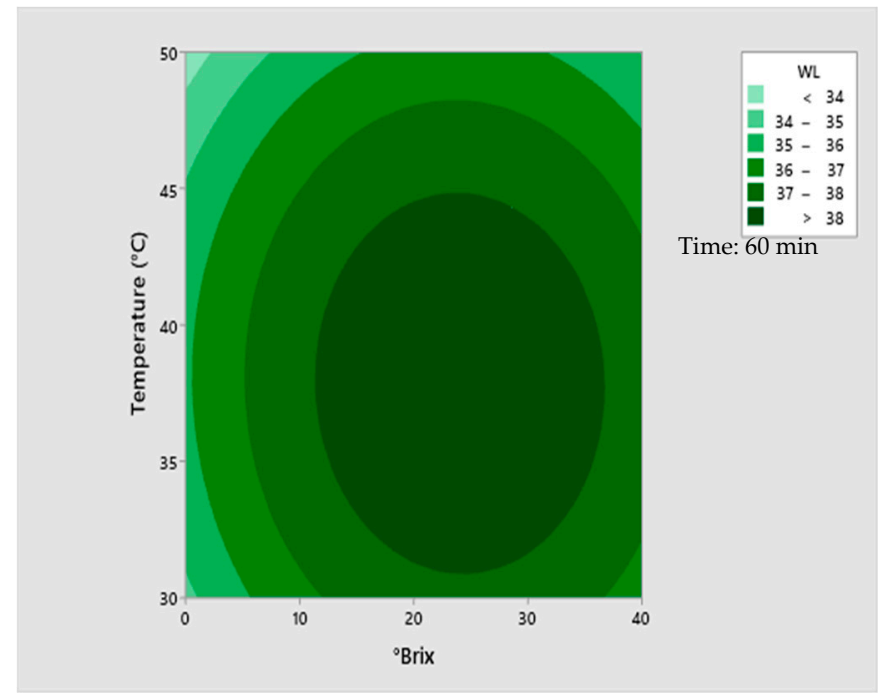

(b)

Figure 1. Influence of time $-{ }^{\circ}$ Brix and temperature $-{ }^{\circ}$ Brix on water loss (a) using, respectively, erythritol (a) and sorbitol (b) osmotic agents.

The models as fitted (Tables 3-5) correspond to Equations (9)-(11):

$\mathbf{W L}(\mathbf{\%})_{(\text {Erythritol })}=43.7+0.067$ Temperature $+0.442{ }^{\circ}$ Brix +0.00497 Temperature *

Temperature $+0.00271^{\circ}$ Brix ${ }^{*}$ Brix +0.01397 Time ${ }^{*}$ Brix

$\mathbf{W L}(\mathbf{\%})_{(\text {Sorbitol })}=39.6+0.097^{\circ}$ Brix +0.00515 Temperature ${ }^{*}$

Temperature +0.017 Time $*$ Time +0.0033 Temperature ${ }^{*}$ Brix

$\mathbf{W L}(\%)_{(\text {Sucrose })}=32.3+0.498$ Temperature +2.240 Time

\subsubsection{Solid Gain (SG)}

Results in Tables 3-5 revealed that only the linear term of temperature was highly significant at $p<0.05$ for all osmotic agents. In fact, the enhancement of temperature decreases the viscosity of the osmotic solution and the resistance to the mass transfer between the osmotic solution and the surface, thus facilitating the outflow of water from the sample and the diffusion rate of solute into the sample [25].

The coefficients estimated for SG was higher in samples treated with erythritol (4.2) than the sorbitol (3.1) and sucrose (0.65) osmotic agents. This difference could be due to the different molecular weights. Indeed, solutes with high molecular weight are more likely to be retained on the surface of the tissue. Otherwise, smaller molecules diffuse more easily through the product matrix $[27,28]$. Therefore, erythritol diffuses more easily through the cells favoring the increase of SG, due to its lower molecular weight. Similar results were reported previously with the OD of yacon in solutions of erythritol, sorbitol, maltitol, xylitol, and sucrose [4]. The same relationship was shown with another food matrix. Indeed, Sritongtae et al. [29] and Mendonça et al. [4] observed a similar situation showing the highest SG in yacon roots with an erythritol solution. The preservation of the original characteristics of the food was better when the solid gain was lower [30]. Therefore, as erythritol favored a great SG, it features a disadvantage compared to the other tested osmotic agents. 
The model developed in the uncoded form of the process variable is given in Equations (12)-(14):

$$
\begin{gathered}
\text { SG (\%) })_{(\text {Erythritol })}=4.2+0.440 \text { Temperature }+0.01282{ }^{\circ} \text { Brix } * \text { Time } \\
\text { SG }(\%)_{(\text {Sorbitol })}=3.1+0.755 \text { Temperature }
\end{gathered}
$$

SG $(\%)_{(\text {Sucrose })}=0.65+0.1233$ Temperature +0.00286 Temperature ${ }^{*}$ Temperature

\subsubsection{Weight Reduction (WR)}

Table 3 shows that the linear terms of temperature and ${ }^{\circ}$ Brix have a significant $(p<0.05)$ impact on the WR when the erythritol osmotic agent was used. On the other hand, the quadratic term of time and the linear term of temperature have a significant impact $(p<0.05)$ on WR when using the sorbitol solution. Maldonado et al. [31] revealed similar results showing that the temperature, the time, and their interaction were important factors affecting WR during the OD of yacon slices. Table 5 shows that only the quadratic term of time has an influence on WR when using the sucrose agent. Similar behavior has been reported in other studies of OD, such as Taiwo et al. [32], who worked with strawberries in a sucrose osmotic solution.

The coefficient values indicate that the temperature has the maximum positive contribution for the erythritol and sorbitol osmotic agents $\left(\beta_{\text {erythritol }}=0.370 ; \beta_{\text {sorbitol }}=1.049\right)$, followed by ${ }^{\circ} \operatorname{Brix}\left(\beta_{\text {erythritol }}=0.234\right)$ and time ${ }^{2}\left(\beta_{\text {sorbitol }}=0.0426\right)$. The coefficient estimated for WR (46.4) when using the erythritol osmotic agent was higher than that using the sorbitol (44.7) or sucrose (40.5) agent. Results indicate the significant influence of low molecular weight in enhancing the WR of seeds during the OD process.

The experimental results for the WR were fitted well to Equations (15)-(17) after the elimination of nonsignificant terms:

$$
\text { WR }(\%)_{(\text {Erythritol })}=46.4+0.370 \text { Temperature }+0.234^{\circ} \text { Brix }
$$

$$
\begin{gathered}
\text { WR }(\%)_{(\text {Sorbitol })}=44.7+1.049 \text { Temperature }+0.0426 \text { Time }^{*} \text { Time } \\
\text { WR }(\%)_{(\text {Sucrose })}=40.5+0.0609 \text { Time }^{*} \text { Time }
\end{gathered}
$$

\subsubsection{Effective Diffusivity $\left(\mathrm{D}_{\text {eff }}\right)$}

The impact of diffusivity values for water and the experimental data of Peleg's equation parameters $\left(\mathrm{K}_{1}\right.$ and $\left.\mathrm{K}_{2}\right)$ revealed a good fit to the experimental data, as the average correlation coefficients $\left(R^{2}\right)$ were very close to 1 (0.9999). The experimental values for $\mathrm{D}_{\text {eff }}$ were an order of magnitude between $1.75 \times 10^{-8}<\mathrm{D}_{\text {eff }}<4.74 \times 10^{-8}$ for erythritol; $1.73 \times 10^{-8}<\mathrm{D}_{\text {eff }}<4.80 \times 10^{-8}$ for sorbitol and $1.20 \times 10^{-8}<\mathrm{D}_{\text {eff }}<4.70 \times 10^{-8}$ for the sucrose agent. The $\mathrm{D}_{\text {eff }}$ shows the same order of magnitude for all models and were analogous to those published by different food matrices, like strawberry, mango, pineapple, and jumbo squid [33-35]. Results showed that $\mathrm{D}_{\text {eff }}$ did not varied significantly using any osmotic agents. Tables 3-5 demonstrate that only the linear term of time and temperature were highly significant $(p<0.05)$ for all osmotic solutions. In addition, $\mathrm{D}_{\text {eff }}$ indicates the maximum positive contribution of time (erythritol: $\beta=0.475 \times 10^{-8}$; sorbitol: $\beta=0.432 \times 10^{-8}$; sucrose: $\beta=0.101 \times 10^{-8}$ ) followed by temperature (erythritol: $\beta=0.0182 \times 10^{-8}$; sorbitol: $\beta=0.007 \times 10^{-8}$; sucrose: $\beta=0.0275 \times 10^{-8}$ ).

The estimated coefficients for the $\mathrm{D}_{\text {eff }}$ of water when using polyol solutions (erythritol: $6.35 \times 10^{-8}$; sorbitol: $5.80 \times 10^{-8}$ ) have the highest value compared to the sucrose treatment $\left(4.23 \times 10^{-8}\right)$. Therefore, the use of polyol increases water diffusivity from seeds to the osmotic solution compared to the sucrose agent. Indeed, Kowalska et al. [1] reported that the smaller the molecular weight, the greater the diffusivity of the substance in the dehydrated apples. In addition, Corrêa et al. [30] indicated similar results showing that the erythritol and sorbitol osmotic agent promoted a higher chemical potential of the osmotic solution and, consequently, more intense flows of water and solids through 
the yacon matrix. Mendonça et al. [4] showed that the $\mathrm{D}_{\text {eff }}$ for water and solids was higher for samples treated in solutions of lower molecular weight solutes. The $\mathrm{D}_{\text {eff }}$ results corroborated our previous results for WL using polyol agents.

The models as fitted are given in Equations (18)-(20):

$$
\begin{gathered}
\mathbf{D}_{\text {eff }}(\mathbf{\%})_{(\text {Erythritol })}=6.35 \times 10^{-8}+0.0182 \times 10^{-8} \text { Temperature }+0.475 \times 10^{-8} \text { Time } \\
\mathbf{D}_{\text {eff }}(\mathbf{\%})_{(\text {Sorbitol })}=5.80 \times 10^{-8}+0.007 \times 10^{-8} \text { Temperature }+0.432 \times 10^{-8} \text { Time } \\
\mathbf{D}_{\text {eff }}(\%)_{(\text {Sucrose })}=4.23 \times 10^{-8}+0.0275 \times 10^{-8} \text { Temperature }+0.101 \times 10^{-8} \text { Time }
\end{gathered}
$$

\subsubsection{Optimization and Validation of the Models}

According to the software optimization step, the response SG was defined as "minimum" and the responses WR, WL, and $D_{\text {eff }}$ were defined as "maximum". The optimum conditions for erythritol, sorbitol, and sucrose agents were found to be ${ }^{\circ}$ Brix: 40/27.77/31.81; temperature: $30 / 37.67 / 42.52$; time: 10/13.03/43.33, respectively, with an overall desirability value of $0.7423 / 0.8015 / 0.8720$. At this optimum condition, WL, WR, SG, and $\mathrm{D}_{\text {eff }}$ were found to be $41.34 \%, 40.01 \%, 1.98 \%$, and $4.15 \times 10^{-8} \mathrm{~m}^{2} / \mathrm{s}$, respectively, for the erythritol agent. The optimum condition for sorbitol agents corresponds to: WL: $38.61 \%$; SG: $-0.37 \%$; WR: $37.77 \%$; $\mathrm{D}_{\text {eff: }} 4.01 \times 10^{-8} \mathrm{~m}^{2} / \mathrm{s}$. The use of sucrose as an osmotic agent decreased WL compared to the other osmotic agents. In fact, the optimum condition corresponds to: WL: $36.17 \%$; SG: -4.18 ; WR: $32.81 ; \mathrm{D}_{\text {eff }}: 3.90 \times 10^{-8} \mathrm{~m}^{2} / \mathrm{s}$. This fact is due to the low molecular weight of erythritol and sorbitol compared to sucrose, which involves an increase of osmotic pressure. Cichowska et al. [11] revealed that erythritol $(6396.87 \mathrm{kPa})$ and xylitol $(5134.16 \mathrm{kPa})$ have the higher osmotic pressure because of a lower molecular weight compared to maltitol $(2270.28 \mathrm{kPa})$ and sucrose $(2080.46 \mathrm{kPa})$. Results for the optimum SG showed that erythritol favored a high SG; it features a disadvantage compared to the other tested osmotic agents, despite the high WL\%. Similar findings were indicated by Barbosa Sritongtae et al. [29], Viana et al. [27], and Mendonça et al. [4].

\subsubsection{Predictive Capacity of the Response Surface Models}

Three experiments were performed under the recommended optimum conditions to confirm the predictive capacity of the response surface models. The observed experimental values were found to be for WL: 36.56\% (sorbitol), 39.14\% (erythritol), and 33.09\% (sucrose); WR: 34.26\% (sorbitol), 36.63\% (erythritol), and 30.85\% (sucrose); SG: -1.03\% (sorbitol), $1.52 \%$ (erythritol), and $-6.40 \%$ (sucrose); $\mathrm{D}_{\text {eff }}: 4.28 \times 10^{-8} \mathrm{~m}^{2} / \mathrm{s}$ (sorbitol), $4.55 \times 10^{-8} \mathrm{~m}^{2} / \mathrm{s}$ (erythritol), and $4.16 \times 10^{-8} \mathrm{~m}^{2} / \mathrm{s}$ (sucrose), respectively. The difference between the experimental and the predicted values were very minor, exhibiting the adequacy of the models fitted by response surface methodology and thus, confirming the predictability of WL, $\mathrm{D}_{\text {eff }}, \mathrm{SG}$, and WR in the experimental conditions used.

The preservation of the original characteristics of the food was positively influenced by a low amount of SG [30]. Therefore, osmotically dehydrated seeds with a small value of SG connected with a high rate of WL are desirable. Based on our result, the use of sorbitol as an osmotic agent satisfies all these conditions compared to erythritol and sucrose agents.

\subsection{The Effect of Polyol on Color Changes of Pomegranate Seeds during OD Process}

As reported by Mothibe et al. [36], color is the principal parameter that customers use in order to decide the quality of products. Using the recommended optimum condition and during the OD of pomegranate seeds in erythritol and sorbitol solutions, an increase of brightness ( $L^{*}$ : from 29.82 to $\sim 45.2$ ) and parameter $b^{*}$ (from 9.81 to $\sim 15.35$ ) and a decrease of parameter $a^{*}$ (from 18.98 to $\sim 7.20$ ) were shown. The brightness was higher, probably due to sugar-coating after an OD process. This substance has a high crystallization capacity [32]. In addition, this variation could be also explained by the nonenzymatic browning and the migration of pigment (anthocyanin) from the pulp to the solution [20]. The OD of seeds in a sucrose solution presents a small difference $\left(L^{*}: 35.08 \pm 0.01 ; a^{*}: 11.12 \pm 0.05 ; b^{*}\right.$ : 
$10.01 \pm 0.01)$, characterized by the lowest $L^{*}$ and $b^{*}$ values and the highest $a^{*}$ parameter. This variation between reference (sucrose) and polyol agent (erythritol, sorbitol) could be due to the different optimal conditions. The color difference $(\Delta \mathrm{E})$ showed the greater impact of the polyol osmotic agent during the OD of pomegranate seeds, taking fresh seeds as a reference. Indeed, the seeds treated with erythritol have higher $\Delta \mathrm{E}$ (25.59), followed by sorbitol ( $\triangle \mathrm{E}: 22.57)$ and sucrose $(\Delta \mathrm{E}: 10.05)$. These variations could be due to the higher mass transfer (water, pigment, sugar etc.) induced by polyol agents (erythritol and sorbitol). In fact, Zaouay and Mars [37] indicated a significant loss of anthocyanin pigment from pomegranate seeds during the OD process.

\subsection{The Effect of Polyol on Texture Changes}

Using the recommended optimum condition for sucrose and sorbitol, results showed a significant difference $(p<0.05)$ between the texture of different seeds compared to fresh seeds (Figure 2). Indeed, hardness values of OD seeds in sorbitol $(86.0 \pm 1 \mathrm{~N})$ and sucrose $(78.0 \pm 1 \mathrm{~N})$ osmotic solutions were higher than that of fresh seeds $(56.5 \pm 0.50 \mathrm{~N})$. This fact was due to the high amount of WL and SG during the osmotic dehydration of seeds in sorbitol solution. In fact, WL involves the plasmolysis of cells, and SG gives consistency to the tissues and thus strengthens the cell structure. Nunes et al. [38] and Chauhan et al., [28] showed that small molecules such as sorbitol diffuse more easily through the product matrix during the OD process and interact with the cell wall and middle lamella, which might result in the formation of a jam-like structure that gives consistency to the tissues. Nevertheless, fresh seeds had the highest toughness values (fresh: $190 \pm 1.4 \mathrm{~N} \mathrm{~mm}$; sorbitol: $171.25 \pm 2.5 \mathrm{~N}$; sucrose: $178.50 \pm 1.5$ ). Therefore, the energy required to crush the sample completely decreased with the increase of WL in seeds. This could be explained by cell membrane deterioration during the OD process involving the loss of binding capacity among cell walls. Similar results were reported previously with the OD of pomegranate seeds using sucrose osmotic solutions [39].

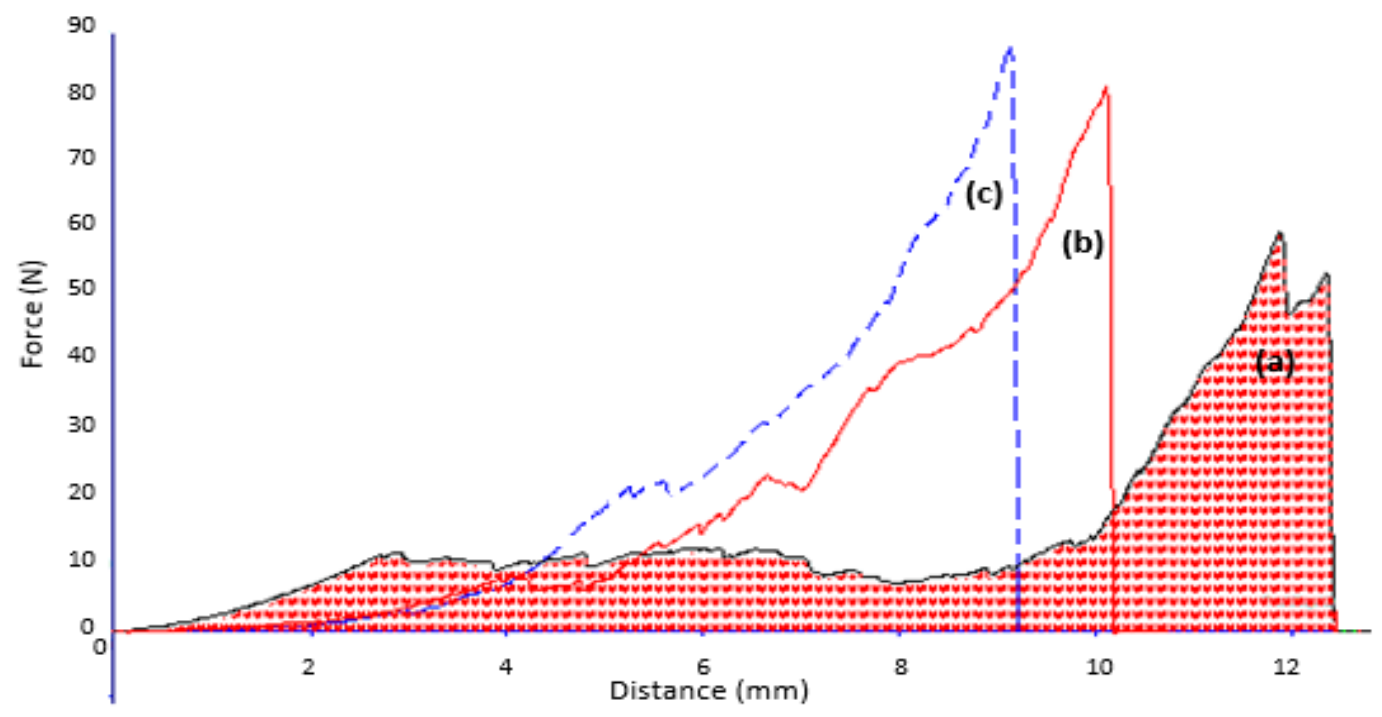

Figure 2. Characterization force-distance curve for texture analysis: fresh seeds (a); osmodehydrated seeds using sucrose (b) and sorbitol (c) osmotic agents.

\section{Conclusions}

The polyols, erythritol, and sorbitol, are suitable for use as osmotic agents in the dehydration of pomegranate seeds. Using these solutions delivers an alternative to the use of sucrose, which is usually used in the food industry. The optimal conditions for maximum WL (38.61\%), WR $(37.77 \%)$ and $\mathrm{D}_{\text {eff }}\left(4.01 \times 10^{-8} \mathrm{~m}^{2} / \mathrm{s}\right)$ and minimum solid gain $(-0.37 \%)$ were $13.03 \mathrm{~min}, 27.77^{\circ} \mathrm{Brix}$, and $37.7^{\circ} \mathrm{C}$ for the OD of seeds using the 
sorbitol osmotic solution. In fact, the use of erythritol and sucrose gives the maximum SG and the minimum WL, respectively. Considering that a lower SG is highly desirable, the erythritol presents a distinct disadvantage. Therefore, the optimal condition for the sorbitol osmotic agent seems to be the most suitable for the OD of pomegranate seeds since it respects the general condition of minimum SG and maximum WL. The use of Peleg and Fick mathematical models revealed that effective diffusivities of water obtained for all osmotic agents were mainly influenced by time and temperature. The texture and the color difference $(\Delta \mathrm{E})$ showed the important effect of polyol osmotic agents during the $\mathrm{OD}$ of pomegranate seeds. In fact, polyol with a low molecular weight strengthened the cell structure, involving an increase in the seeds' hardness. Furthermore, seed colors became brighter and more attractive.

These results suggest that polyols could be promising compounds for the OD of pomegranate seeds, giving a higher mass transfer than a sucrose agent.

Author Contributions: B.B. designed the experiments and wrote the manuscript. H.S. carried out the experiments. S.B. review and editing. M.A.B. gave instructions in experiments. H.A., S.D. and C.B. supervised the project. All authors have read and agreed to the published version of the manuscript.

Funding: This research was funded by the Ministry of Higher Education and Scientific Research, Tunisia. Institutional Review Board Statement: Not applicable.

Data Availability Statement: Not applicable.

Conflicts of Interest: The authors declare that they do not have any conflict of interest.

\section{References}

1. White, J.S. Sucrose and Fructose: History, Manufacture, Composition, Applications, and Production. Chapter 2. In Fructose, High Fructose Corn Syrup, Sucrose and Health, Nutrition and Health; Rippe, J.M., Ed.; Springer Science Business Media: New York, NY, USA, 2014.

2. Kowalska, H.; Wozniak, C.; Masiarz, E.; Stelmach, A.; Salamon, A.; Kowalska, J.; Marzec, A. The impact of using polyols as osmotic agents on mass exchange during osmotic dehydration and their content in osmo-dehydrated and dried apples. Dry. Technol. 2020, 38, 1620-1631. [CrossRef]

3. O'Donnell, K.; Kearsleya, M. Sweeteners and Sugar Alternatives in Food Technology, 2nd ed.; Wiley: Hoboken, NJ, USA, 2012.

4. Mendonça, K.; Correa, J.; Junqueira, J.; Angelis-Pereira, M.; Cirillo, M. Mass Transfer Kinetics of the Osmotic Dehydration of Yacon Slices with Polyols. J. Food Process. Preserv. 2016, 41, e12983. [CrossRef]

5. Grembecka, M. Natural sweeteners in a human diet. Bibl. Nauki 2015, 66, 3.

6. Aidoo, R.P.; Depypere, F.; Afoakwa, E.O.; Dewettinck, K. Industrial manufacture of sugar-free chocolates-Applicability of alternative sweeteners and carbohydrate polymers as raw materials in product development. Trends Food Sci. Technol. 2013, 32, 84-96. [CrossRef]

7. Phisut, N.; Rattanawedee, M.; Aekkasak, K. Effect of Different Osmotic Agents on the Physical, Chemical and Sensory Properties of Osmo-Dried Cantaloupe. Chiang Mai J. Sci. 2013, 40, 427-439.

8. Nowacka, M.; Tylewicz, U.; Tappi, S.; Siroli, L.; Lanciotti, R.; Romani, S.; Witrowa-Rajchert, D. Ultrasound assisted osmotic dehydration of organic cranberries (Vaccinium oxycoccus): Study on quality parameters evolution during storage. Food Control. 2018, 93, 40-47. [CrossRef]

9. Silva, M.A.D.C.; da Silva, Z.E.; Mariani, V.C.; Darche, S. Mass transfer during the osmotic dehydration of West Indian cherry. LWT 2012, 45, 246-252. [CrossRef]

10. Bialik, M.; Wiktor, A.; Latocha, P.; Gondek, E. Mass Transfer in Osmotic Dehydration of Kiwiberry: Experimental and Mathematical Modelling Studies. Molecules 2018, 23, 1236. [CrossRef] [PubMed]

11. Cichowska, J.; Zubernik, J.; Czyzewski, J.; Kowalska, H.; Witrowa-Rajchert, D. Efficiency of Osmotic Dehydration of Apples in Polyols Solutions. Molecules 2018, 23, 446. [CrossRef]

12. Lowithun, N.; Charoenrein, S. Influence of osmodehydrofreezing with different sugars on the quality of frozen rambutan. Int. J. Food Sci. Technol. 2009, 44, 2183-2188. [CrossRef]

13. Vicente, S.; Nieto, A.B.; Hodara, K.; Castro, M.A.; Alzamora, S.M. Changes in Structure, Rheology, and Water Mo-bility of Apple Tissue Induced by Osmotic Dehydration with Glucose or Trehalose. Food Biopro. Technol. 2012, 5, 3075-3089. [CrossRef]

14. Konopacka, D.; Jesionkowska, K.; Klewicki, R.; Bonazzi, C. The effect of different osmotic agents on the sensory perception of osmo-treated dried fruit. J. Hortic. Sci. Biotechnol. 2009, 84, 80-84. [CrossRef]

15. Nieto, A.B.; Vicente, S.; Hodara, K.; Castro, M.A.; Alzamora, S.M. Osmotic dehydration of apple: Influence of sugar and water activity on tissue structure, rheological properties and water mobility. J. Food Eng. 2013, 119, 104-114. [CrossRef] 
16. Dermesonlouoglou, E.K.; Giannakourou, M.; Taoukis, P.S. Kinetic study of the effect of the osmoticdehydration pre-treatment with alternative osmotic solutes to the shelf life of frozen strawberry. Food Bioprod. Process. 2016, 99, 212-221. [CrossRef]

17. Bchir, B.; Bouaziz, M.A.; Ettaib, R.; Sebii, H.; Danthine, S.; Blecker, C.; Besbes, S.; Attia, H. Optimization of ultrasound-assisted osmotic dehydration of pomegranate seeds (Punica granatum L.) using response surface methodology. J. Food Process. Preserv. 2020, 44. [CrossRef]

18. Cichowska, J.; Woźniak, L.; Figiel, A.; Witrowa-Rajchert, D. The Influence of Osmotic Dehydration in Polyols Solu-tions on Sugar Profiles and Color Changes of Apple Tissue. Period. Polytech. Chem. Eng. 2020, 64, 530-538. [CrossRef]

19. Bchir, B.; Besbes, S.; Attia, H.; Blecker, C. Osmotic dehydration of pomegranate seeds (Punica granatum L.): Effect of freezing pre-treatment. J. Food Process. Eng. 2011, 35, 335-354. [CrossRef]

20. Bchir, B.; Besbes, S.; Attia, H.; Blecker, C. Osmotic dehydration of pomegranate seeds: Mass transfer kinetics and differential scanning calorimetry characterization. Int. J. Food Sci. Technol. 2009, 44, 2208-2217. [CrossRef]

21. Alvarez, A.C.; Aguerre, R.; Gomez, R.; Vidales, S.; Altamira, S.M.; Gerschenson, L.N. Air dehydration of strawber-ries: Effects of blanching and osmotic pretreatments on the kinetics of moisture transport. J. Food Eng. 1995, 25, 167-178. [CrossRef]

22. Palou, E.; Lopez-Malo, A.; Argaiz, A.; Welti, J. Use of Peleg's equation to osmotic concentration of papaya. Dry. Technol. 1994, 12, 965-978. [CrossRef]

23. Khan, M.A.; Shukla, R.N.; Zaidi, S. Mass Transfer during Osmotic dehydration of Apple using Sucrose, Fructose and Maltodextrin Solution. In Proceedings of the 11th International Congress on Engineering and Food, Athens, Greece, 22-26 May 2011; pp. 967-968.

24. Devic, E.; Guyot, S.; Daudin, J.-D.; Bonazzi, C. Effect of Temperature and Cultivar on Polyphenol Retention and Mass Transfer during Osmotic Dehydration of Apples. J. Agric. Food Chem. 2009, 58, 606-614. [CrossRef] [PubMed]

25. Ferrari, C.C.; Hubinger, M.D. Evaluation of the mechanical properties and diffusion coefficients of osmodehydrated melon cubes. Int. J. Food Sci. Technol. 2008, 43, 2065-2074. [CrossRef]

26. Moreira, R.; Chenlo, F.; Torres, M.; Vazquez, G. Effect of stirring in the osmotic dehydration of chestnut using glycerol solutions. LWT 2007, 40, 1507-1514. [CrossRef]

27. Viana, A.D.; Corrêa, J.L.; Justus, A. Optimisation of the pulsed vacuum osmotic dehydration of cladodes of fodder palm. Int. J. Food Sci. Technol. 2013, 49, 726-732. [CrossRef]

28. Chauhan, O.P.; Singh, A.; Singh, A.; Raju, P.S.; Bawa, A.S. Effects of Osmotic Agents on Colour, Textural, Struc-tural, Thermal, and Sensory Properties of Apple Slices. Int. J. Food Prop. 2011, 14, 1037-1048. [CrossRef]

29. Sritongtae, B.; Mahawanich, T.; Duangmal, K. Drying of Osmosed Cantaloupe: Effect of Polyols on Drying and Water Mobility. Dry. Technol. 2011, 29, 527-535. [CrossRef]

30. Corrêa, J.L.G.; Pereira, L.M.; Vieira, G.S.; Hubinger, M.D. Mass transfer kinetics of pulsed vacuum osmotic dehy-dration of guavas. J. Food Eng. 2010, 96, 498-504. [CrossRef]

31. Maldonado, S.; Santapaola, J.E.; Singh, J.; Torrez, M.; Garay, A. Cinetica de la transferencia de massa durante la deshidratacion osmotica de yacon (Smallanthus sonchifolius). Cienc. Tecnol. Alimen. 2008, 28, 251-256. [CrossRef]

32. Taiwo, K.A.; Eshtiaghi, M.N.; Ade-Omowaye, B.I.O.; Knorr, D. Osmotic dehydration of strawberry halves: Influ-ence of osmotic agents and pretreatment methods on mass transfer and product characteristics. Int. J. Food Sci. Technol. 2003, 38, 693-707. [CrossRef]

33. Peleg, M. An Empirical Model for the Description of Moisture Sorption Curves. J. Food Sci. 1988, 53, 1216-1217. [CrossRef]

34. Uribe, E.; Miranda, M.; Vega, A.; Quispe, I.; Claver, R.; Scala, K. Mass transfer modelling during osmotic dehy-dration of jumbo squid (Dosidicus gigas): Influence of temperature on diffusion coefficients and kinetic parameters. Food Bioproc. Technol. 2011, 4, 320-326. [CrossRef]

35. Silva, K.S.; Fernandes, M.A.; Mauro, M.A. Osmotic Dehydration of Pineapple with Impregnation of Sucrose, Calcium, and Ascorbic Acid. Food Bioprocess Technol. 2013, 7, 385-397. [CrossRef]

36. Mothibe, K.J.; Zhang, J.M.; Nsoratindana, Y.; Wang, C. Use of ultrasound pretreatment in drying of fruits: Drying rates, quality attributes, and shelf-life extension. Dry. Technol. 2011, 29, 1611-1621. [CrossRef]

37. Zaouay, F.; Mars, M. Phenotypic variation, and estimation of genetic parameters to improve fruit quality in Tunisi-an pomegranate (Punica granatum L.) accessions. J. Horticult. Sci. Biotechnol. 2014, 89, 221-228. [CrossRef]

38. Nunes, C.; Santos, C.; Pinto, G.; Lopes-Da-Silva, J.A.; Saraiva, J.A.; Coimbra, M.A. Effect of candying on microstructure and texture of plums (Prunus domestica L.). LWT 2008, 41, 1776-1783. [CrossRef]

39. Khoualdia, B.; Ben-Ali, S.; Hannachi, A. Pomegranate arils osmotic dehydration: Effect of pre-drying on mass transfer. J. Food Sci. Technol. 2020, 57, 2129-2138. [CrossRef] 